\title{
ANALISIS PROMOSI TERHADAP DANA PIHAK KETIGA DI PERBANKAN SYARIAH
}

\author{
Tria Yolanda \\ Institut Agama Islam Negeri Batusangkar \\ triayolanda14@gmail.com
}

\begin{abstract}
The purpose of this research is to describe the promotion analysis of third party funds in syriah banking. The type of research used is literature review. which contains theoretical theories that are relevant to research problems. The results of this study can be concluded that in increasing third party funds through promotion can be done: Advertising, Sales Promotion, Personal Selling, Public Relations (Public Relations), Direct Marketing (Direct Marketing)
\end{abstract}

Keywords: Dana Pihak Ketiga, Promosi, Perbankan Syariah

\section{PENDAHULUAN}

Pada saat ini pembangunan ekonomi tidak dapat dilepaskan dari sektor perbankan, karena perbankan memegang peranan penting dalam pertumbuhan stabilitas ekonomi. Bank untuk bisa menjaga kepercayaan masyarakat, maka harus menjaga kinerja keuangannya. Kinerja keuangan suatu bank dinilai dengan berbagai indikator. Salah satunya adalah laporan keuangan bank tersebut (Anggraini, 2014)

Sebagai lembaga keuangan yang memiliki fungsi intermediasi keuangan, bank syariah melakukan penghimpunan dana dari masyarakat dalam bentuk simpanan yang disebut juga Dana Pihak Ketiga dan menyalurkan dana tersebut melalui skim pembiayaan baik pembiayaan yang menggunakan prinsip jual beli, sewa, maupun bagi hasil

Sumber dana adalah hal yang paling penting bagi bank untuk meningkatkan jumlah kredit yang akan di salurkan kepada masyarakat. Dalam memberikan kredit, sektor perbankan sangat memerlukan ketersediaan dana. Semakin banyak dana bank, maka semakin besar peluang bank menjalankan fungsinya. Dana pihak ketiga (DPK) merupakan dana yang bersumber dari masyarakat luas merupakan sumber penting untuk aktivitas operasional bank dan merupakan tolak ukur keberhasilan suatu bank apabila bank dapat menanggung biaya operasinya dari sumber dana ini. (Andreany, 2011) 
Dana Pihak Ketiga (DPK) atau simpanan dana yang dipercayakan oleh masyarakat kepada bank berdasarkan perjanjian penyimpanan dana dalam bentuk giro, tabungan, deposito dan atau bentuk lainnya yang dipersamakan dengan itu (Sagita, 2010). Sumber-sumber penghimpunan dana (tidak termasuk modal) perbankan syariah secara umum didominasi oleh Dana Pihak Ketiga (Aziza, 2017)

Bank diharapkan selalu berada ditengah masyarakat, agar aliran uang dari masyarakat yang mempunyai kelebihan dana dapat ditampung kemudian disalurkan kembali kepada masyarakat. Keuntungan utama bank berasal dari sumber sumber dana dengan bunga yang akan diterima dari alokasi tertentu. DPK meningkat maka bank mempunyai peluang serta kesempatan yang

Pada dasarnya, produk yang ditawarkan oleh bank syariah meliputi penyaluran dana dalam bentuk pembiayaan, penghimpunan dana dalam bentuk simpanan yang disebut DPK, dan jasa. Dewasa ini, pembiayaan pada perbankan syariah mengalami perkembangan yang sangat signifikan. Tujuan pembiayaan berdasarkan prinsip syariah adalah untuk meningkatkan kesempatan kerja dan kesejahteraan ekonomi sesuai dengan nilai-nilai Islam Secara garis besar, produk pembiayaan pada bank syariah diklasifikasikan menjadi empat: pembiayaan dengan prinsip jual beli, pembiayaan dengan prinsip sewa, pembiayaan dengan akad pelengkap dan pembiayaan dengan prinsip bagi hasil

Situasi perbankan yang demikian, seluruh perbankan termasuk perbankan syariahikut berlomba mengejar para nasabahnya dengan cara melakukan promosi guna untuk meningkatkan jumlah nasabahnya. Promosi merupakan bagian dari rangkaian kegiatan pemasaran, dan aktivitas promosi adalah bagaimana cara mengkomunikasikan suatu pesan (produk) kepada publik. Aktivitas tersebut menyangkut sejumlah aspek yang terkait dengan produk salah satu aktivitas promosi adalah melalui event, bank memanfaatkan event sebagai mediator pesan perusahaan dalam mencapai sasaran. Salah satu alat promosi yang kini semakin digemari banyak bank adalah promosi tabungan, selain mudah, juga tidak membutuhkan biaya yang besar.

\section{KAJIAN TEORI}

\section{Dana Pihak Ketiga}

Bank berperan sebagai lembaga pelayanan masyarakat dan bertindak sebagai wadah perantara dalam menampung keuangan masyarakat. Dalam hal ini, maka bank diharapkan 
mampu berada ditengan-tengah masyarakat agar arus uang dari masyarakat yang kelebihan dapat ditampung dan disalurkan pada masyarakat yang kekurangan. Sehingga dengan adanya perbankan mampu mengubah arus perekonomian menjadi lebih baik. Tampilnya kepercayaan masyarakat akan kehadiran bank dan keyakinan masyarakat bahwa bank akan memberikan solusi sebaik-baiknya dari permasalahan keuangannya, merupakan suatu keadaan yang diharapkan oleh semua bank. Menurut UU No. 21 Tahun 2008 pasal 1 tentang perbankan syariah disebutkan bahwa Simpanan adalah dana yang dipercayakan oleh nasabah kepada Bank Syariah dan/atau UUS berdasarkan Akad wadi'ah atau Akad lain yang tidak bertentangan dengan Prinsip Syariah dalam bentuk Giro, Tabungan, atau bentuk lainnya yang dipersamakan dengan itu. Dana-dana masyarakat yang ditampung bank merupakan sumber dana terbesar yang dapat diandalkan bank dalam mengoperasikan kegiatannya yang terdiri dari 3 jenis, yaitu: dalam bentuk giro, deposito, dan tabungan.

\section{Sumber Dana Bank Syariah}

Bank Syariah sebagai suatu lembaga keuangan yang salah satu fungsinya adalah menghimpun dana masyarakat, harus memiliki suatu sumber untuk menghimpun dana sebelum disalurkan kemasyarakat kembali. Sumber dana Bank Syariah terdiri dari:

a. Modal inti (core capital). Modal ini adalah dana modal sendiri yaitu dana yang berasal dari pemegang saham bank yakni pemilik bank. Pada umumnya dana modal inti terdiri dari :

1) Modal yang disetor oleh para pemegang saham. Sumber utama dari modal perusahaan adalah saham. Sumber dana ini hanya akan timbul apabila pemilik menyertakan dananya pada bank melalui pembelian saham dan untuk penambahan dana berikutnya dapat dilakukan oleh bank dengan mengeluarkan dan menjual tambahan saham.

2) Cadangan, yaitu sebagian laba bank yang tidak dibagi, yang disisihkan untuk menutup timbulnya resiko kerugian dikemudian hari

3) Laba ditahan, yaitu sebagian laba yang seharusnya dibagi kepada para pemegang saham, tetapi oleh para pemegang saham sendiri (melalui rapat Umum Pemegang Saham) diputuskan untuk ditanam kembali dalam bank. Laba ditahan ini juga merupakan 
cara untuk menambah dana modal lebih lanjut (Sari, 2016 )

b. Dana dan deposan

Pada dasarnya, sumber dana dan masyarakat dapat berupa giro (demand deposit), tabungan (saving deposit), dan deposito berjangka (time deposit) yang berasal dari nasabah perorangan atau badan usaha.

1) Giro

Rekening giro atau checking account adalah simpanan yangpenarikannya dapat dilakukan setiap saat dengan menerbitkan cek untukpenarikan tunai atau bilyet giro untuk pemindahbukuan. Cek atau bilyet giro dapat digunakan oleh pemiliknya sebagai alat pembayaran.Untuk itu, pemegang rekening giro memperoleh buku cek dan bilyet giro. Karena sifat penarikannya yang dapat dilakukan setiap saat, sumber dana dan rekening giro ini merupakan sumber dana jangka pendek yang jumlahnya relatif lebih dinamis atau berfluktuasi dari waktu ke waktu. Bagi nasabah pemegang rekening giro, sifat penarikan tersebut sangat membantu dalam membiayai kegiatan mereka secara lebih efisien.

2) Deposito
Deposito berjangka adalah simpanan yang penarikannya hanyadapat dilakukan pada waktu tertentu sesuai tanggal yang diperjanjikan antara deposan dan bank. Mengingat simpanan ini hanya dapat dicairkan pada saat jatuh temponya oleh pihak yang namanya tercantum dalam bilyet deposito sesuai tanggal jatuh temponya, deposito berjangka ini merupakan simpanan atas nama. Apabila deposan menghendaki agar deposito berjangkanya dapat diperpanjang secara otomatis, pihak bank dapat memberikan fasilitas ARO atau Automatic Roll-Over atas deposito berjangka tersebut.

Kelebihan deposito berjangka ini adalah dapat ditarik tunai setiap jangka waktu tertentu ataupun ditransfer ke rekening deposan. Nasabah biasanya membuka rekening tabungan untuk menampung bunga atas deposito tersebut dan menampung dana deposito yang telah jatuh tempo dan tidak diperpanjang lagi. Bank-bank tertentu juga memberikan fasilitas agar bunga deposito yang tidak ditarik oleh pemiliknya dapat ditambahkan dalam simpanan pokok deposito 
sehingga nilai deposito berjangkanya bertambah besar. Pada dasarnya, sebelum jatuh tempo, simpanan ini tidak dapat ditarik, tetapi apabila pihak deposan tetap menginginkan penarikan sebelum jatuh tempo, biasanya bank mengenakan denda atau biaya administrasi atas penarikan tersebut.

3) Tabungan

Tabungan adalah simpanan yang penarikannya hanya dapat dilakukan dengan syarat tertentu yang disepakati, dan tidak dengan cek atau bilyet giro atau alat lain yang dapat dipersamakan dengan itu. Cara penarikan rekening tabungan yang paling banyak digunakan saat ini adalah dengan buku tabungan, cash card atau kartu ATM, dan debet card. Persaingan ketat dalam penghimpunan dana melalui tabungan antar bank telah banyak memunculkan cara baru untuk menarik nasabah tabungan. Cara-cara tersebut antara lain hadiah atas tabungan, fasilitas asuransi atas tabungan, fasilitas kartu ATM, dan fasilitas debet card. Ditinjau dari segi keluwesan penarikan dana, simpanan dalam bentuk tabungan berada di tengahtengah antara giro dan deposito berjangka. Tabungan dapat ditarik dengan caracara dan dalam waktu yang relatif lebih fleksibel dibandingkan dengan deposito berjangka, tetapi masih lebih fleksibel apabila dibandingkan dengan rekening giro.

\section{METODOLOGI}

Jenis penelitian ini adalah kajian pustaka. Adapun metode penelitian kajian pustaka atau studi kepustakaan yaitu berisi teori teori yang relevan dengan masalah - masalah penelitian. Pada bagian ini dilakukan pengkajian mengenai konsep dan teori yang digunakan berdasarkan literatur yang tersedia, terutama dari artikel-artikel yang dipublikasikan dalam berbagai jurnal ilmiah. Kajian pustaka berfungsi untuk membangun konsep atau teori yang menjadi dasar studi dalam penelitian

\section{PEMBAHASAN}

Menurut Metia dalam aghassanni bank adalah badan usaha yang menghimpun dana dari masyarakat dalam bentuk simpanan dan menyalurkannya kepada masyarakat dalam bentuk kredit dan atau bentuk-bentuk lainnya dalam rangka meningkatkan taraf hidup rakyat banyak". Sedangkan menurut Pebriani dalam aghasanni bank adalah badan usaha yang 
menghimpun dana dari masyarakat dalam bentuk simpanan dan menyalurkan kemasyarakat dalam rangka meningkatkan taraf hidup orang banyak.

\section{Pemasaran}

berkembangnya kemajuan ilmu pengetahuan dan teknologi, gaya hidup manusia terutama mengenai pemilihan makanan yang akan dikonsumsi akan semakin beragam. Hal ini dikarenakan lahirnya segala macam jenis produk dari ide-ide yang kreatif. Dengan demikian perusahaan dalam menjalankan usahanya perlu mengenmbangkan strategi pemasarannya, agar mampu bertahan dalam persaingan usaha yang beragam. Pemasaran merupakan salah satu aspek penting dalam kegiatan bisnis. Perusahaan dalam menjalankan usahanya perlu mengembangkan strategi pemasarannya, agar mampu bertahan dalam persaingan usaha yang beraneka ragam, yang berdampak pada persaingan usaha yang sejenis (Adhaghassani, 2016).

Menurut Irawan Dimana pemasaran dapat diartikan sebagai sebuah proses sosial dan manajerial dari individu atau kelompok pembeli dalam mendapatkan apa yang mereka butuhkan dan inginkan melalui penciptaan, penawaran dan pertukaran produk yang bernilai dengan individu atau kelompok lainnya. Kegiatan pemasaran jasa harus dapat mendekatkan konsumen, pelanggan, mengkaji peluang-peluang pasar, menetapkan posisi jasa segmen pasar dan pasar sasaran atas dasar keb utuhan jasa tersebut serta merumuskan bauran pemasaran (marketingmix), yang meliputi mutu dan deversifikasi jasa, harga atau tarif dari kegiatan promosi dan strategi penyampaian jasa tersebut. Marketing mix (Bauran Pemasaran Jasa) Salah satu strategi yang berhubungan dengan kegiatan pemasaran perusahaan :

1. Product (Produk) Produk yaitu segala sesuatu yang ditawarkan kepada pangsa pasar agar diperhatikan, diminta, dipakai, atau dikonsumsi sehingga memuaskan kebutuhan atau keinginan konsumen. Istilah produk mempunyai bermacammacam arti dan makna. Produk adalah segala sesuatu yang dapat ditawarkan ke pasar untuk menarik perhatian, pembelian atau dikonsumsi yang dapat memuaskan keinginan atau kebutuhan (Kaharu \& Budiarti, 2016)

2. Price (Harga) Harga merupakan salah satu variabel penting dalam pemasaran, dimana harga dapat mempengaruhi konsumen dalam mengambil keputusan untuk membeli suatu produk, karena 
berbagai alasan. Alasan ekonomis akan menunjukkan harga yang rendah atau harga terlalu berkompetisi merupakan salah satu pemicu penting untuk meningkatkan kinerja pemasaran, tetapi alasan psikologis dapat menunjukkan bahwa harga justru merupakan indikator kualitas dan karena itu dirancang sebagai salah satu instrumen penjualan sekaligus sebagai instrument kompetisi yang menentukan (Mongi, Mananeke, \& Repi, 2013).

3. Promotion (Promosi) Menurut (Febrianto, 2014) Promosi adalah kegiatan yang dilakukan perusahaan dengan tujuan utama untuk menginformasikan, membujuk, mempengaruhi, dan mengingatkan konsumen agar membeli produk yang dihasilkan. Strategi promosi (promotion strategi) memerlukan adversiting, sales promotion, personal selling, dan publicity keadaan sebuah program yang terkoordinasi untuk berkomunikasi dengan para pembeli dan pihak lainya yang mempengaruhi keputusan pembelian. Aktifitas promosi mempunyai pengaruh penting atas penjualan produk dicapai oleh suatu usaha. Penge lolaan yang efektif atas sumber daya yang mahal tersebut adalah potensial untuk mencapai hasil imbalan optimal dari pengeluaran promosi Sebenarnya tujuan dari promosi adalah mempengaruhi prilaku. Beberapa faktor yang harus diperhatikan dalam menyusun strategi bauran promosi antara lain

a. Faktor Produk, pada produk yang dalam kategori industri dan bersifat teknis bauran pemasaran yang baik adalah personal selling. Selain itu personal selling juga digunakan untuk produk dengan resiko pembeli tinggi, sedangkan pada produk yang dibeli dalam jumlah kecil dengan frekuensi tinggi maka strategi yang digunakan adalah iklan.

b. Faktor Pasar, pada faktor pasar yang diperhatikan adalah product life cycle. Pada tahap perkenalan maka iklan lebih mendominasi. Sedangkan pada masa kedewasaan dan penurunan dibutuhkan strategi iklan dan promosi.

c. Faktor Pelanggan, dilihat dari faktor pelanggan-pelanggan rumah tangga lebih baik menggunakan pendekatan iklan sedangkan jika pelanggan adalah industri maka personal selling lebih tepat. Dalam kaitannya dengan sasaran yang dituju terdapat dua strategi yang bisa digunakan, yaitu push strategy 
yang ditekankan untuk membeli langsung, dan pull strategy.

d. Faktor Anggaran, jika perusahaan memiliki dana promosi yang besar, maka peluangnya untuk menggunakan iklan yang bersifat nasional juga besar.Sebaiknya bila dana terbatas, maka dapat memilih personal selling, promosi penjualan atau iklan bersama di wilayah local atau regional.

e. Faktor Bauran Pemasaran, pada bauran pemasaran sangat menentukan pilihan media promosi baik iklan, personal selling, maupun publisitas.

4. Place (Saluran Distribusi) Menurut Menyatakan bahwa "Saluran distribusi terdiri dari seperangkat lembaga yang melakukan segala kegiatan (Fungsi) yang digunakan untuk menyalurkan produk dan status pemiliknya dari produsen ke konsumen". Dari definisi diatas dapat diartikan bahwa saluran distribusi suatu barang adalah keseluruhan kegiatan atau fungsi untuk memindahkan produk disertai dengan hak pemiliknya dari produsen ke konsumen akhir atau pemakai industri. Distribusi berkaitan dengan kemudahan memperoleh produk di pasar dan tersedia saat konsumen mencarinya. Distribusi memperlihatkan berbagai kegiatan yang dilakukan perusahaan untuk menjadikan produk atau jasa diperoleh dan tersedia bagi konsumen sasaran.

5. People (Partisipan) Orang berfungsi sebagai penyedia jasa sangat mempengaruhi kualitas jasa yang diberikan. Keputusan dalam faktor ini berarti sehubungan dengan seleksi, pelatihan, motivasi, dan manajemen sumber daya manusia, Untuk mencapai kualitas yang terbaik, pegawai harus dilatih untuk menyadari pentingnya pekerjaan mereka. Yaitu memberikan konsumen kepuasan dalam memenuhi kebutuhannya. Pentingnya sumber daya manusia dalam pemasaran jasa berkaitan erat dengan pemasaran. Terdapat dua elemen partisipan, Services people. Memegang jabatan ganda mengadakan jasa dan menjual jasa tersebut. Melalui pelayanan yang baik, cepat, ramah, teliti dan kesetiaan pelanggan terhadap perusahaan yang akhirnya akan meningkatkan nama baik perusahaan. Faktor lain yang mempengaruhi adalah hubungan yang ada diantara para pelanggan. Pelanggan dapat memberikan persepsi kepada konsumen lain, tentang kualitas jasa yang pernah didapatnya dari perusahaan. Keberhasilan manajemen dari 
sumber daya manusia. Pemasaran internal semakin diakui perusahaan jasa dalam menentukan suksesnya pemasaran ke pelanggan eksternal (Yuniati, 2015)

6. Process (Proses) menyatakan bahwa proses ialah semua prosedur aktual, mekanisme dan aliran aktivitas yang digunakan untuk menyampaikan jasa.

7. Physical Evidence (Lingkungan Fisik) Menurut Bukti fisik merupakan lingkungan fisik tempat jasa diciptakan dan langsung berinteraksi dengan konsumen. Ada dua jenis bukti fisik, sebagai berikut:

a. Bukti penting (essential evidence), merupakan keputusan-keputusan yang dibuat oleh pemberi jasa mengenai desain dan tata letak (layout)dari gedung, ruang, dan lain-lain.

b. Bukti pendukung (peripheral evidence), merupakan nilai tambah yang apabila berdiri sendiri maka tidak akan berarti apa-apa. Dengan demikian, hanya berfungsi sebagai pelengkap saja. Sekalipun demikian, peranannya sangat penting dalam proses produksi jasa. Sebagai contoh, tiket pesawat. Bukti fisik membantu pemasar untuk memposisikan perusahaannya di pasar dan memberikan dukungan nyata, terlebih yang berhubungan dengan lokasi (Hidayati, 2018)

\section{KESIMPULAN}

Berdasarkan uraian pada babbab sebelumnya, maka dapat diambil kesimpulan sebagai berikut

1. Iklan (Advertising)

2. Promosi Penjualan

3. Penjualan Perorangan (Personal Selling)

4. Hubungan Masyarakat (Public Relations)

5. Pemasaran Langsung (Direct Marketing)

\section{KEPUSTAKAAN ACUAN}

Anggreni, M. R., \& Suardhika, I. M. S. (2014). Pengaruh dana pihak ketiga, kecukupan modal, risiko kredit dan suku bunga kredit pada profitabilitas. E-Jurnal Akuntansi Universitas Udayana, 9(1)

Andraeny, D. (2011). Analisis Pengaruh Dana Pihak Ketiga, Tingkat Bagi Hasil, dan Non Performing Financing terhadap Volume Pembiayaan Berbasis Bagi Hasil pada Perbankan Syariah di Indonesia. Simposium Nasional Akuntansi XIV 
Aziza, R. V. S., \& Mulazid, A. S. (2017). Analisis Pengaruh Dana Pihak Ketiga, Non Performing Financing, Capital Adequacy Ratio, Modal Sendiri dan Marjin Keuntungan Terhadap Pembiayaan Murabahah. JEBI (Jurnal Ekonomi dan Bisnis Islam)

Sari, N. (2016). Manajemen Dana Bank Syariah. Jurnal Ilmu Syariah: AlMaslahah, 12(1),

Hidayati, R. R., \& Marlius, D. (2018). Aktivitas Promosi Dalam Meningkatkan Dana Pihak Ketiga Pada PT. Bank Perkreditan Rakyat (BPR) Batang Kapas Pesisir Selatan.

Yuniati, T. (2015). Pengaruh Bauran Pemasaran Terhadap Keputusan Konsumen Membeli Kartu Prabayar IM3 (Studi Kasus Pada Mahasiswa Stiesia Surabaya) Dyah Rizky Anggaryani. Jurnal
Ilmu \& Riset Manajemen, 4(November)

Febrianto, M. R. (2014). Pengauh Produk, Harga, Tempat Dan Promosi Terhadap Perilaku Hedonis Pembeli Smartphone Samsung. Jurnal Ilmu \& Riset Manajemen.

Adhaghassani, S. F. (2016). Strategi Bauran Pemasaran (Marketing Mix) 7P (Product, Price, Place, Promotion, People, Process, Physical Evidence di Cherryka Bakery). Pendidikan Teknik Boga, (Marketing Mix), 1-10

Kaharu, D., \& Budiarti, A. (2016). Pengaruh Gaya Hidup, Promosi, dan Kualitas Produk terhadap Keputusan Pembelian pada Cosmic. Jurnal Ilmu dan Riset Manajemen, ISSN : 2461-0593, 5(3), $1-24$. 